\title{
Singlet Oxygen Generation with Chemical Excitation of an Erythrosine-Luminol Conjugate
}

\author{
Nisa Yesilgul, ${ }^{\dagger}$ T. Bilal Uyar, ${ }^{\ddagger}$ Ozlem Seven, ${ }^{\ddagger}$ and Engin U. Akkaya* ${ }^{*}, \ddagger \odot$ \\ ${ }^{\dagger}$ Department of Chemistry and ${ }^{\star}$ UNAM-National Nanotechnology Research Center, Bilkent University, 06800 Ankara, Turkey
}

Supporting Information

ABSTRACT: Chemical generation of singlet oxygen under biologically relevant conditions is very important, considering the role played by singlet oxygen in cancer therapeutics. We now demonstrate that a luminol derivative can be chemically excited and transfer the excitation energy to the covalently attached photosensitizer derived from erythrosin. A photosensitizer module, when excited in this manner, can generate singlet oxygen in solution. As hydrogen peroxide is present in a relatively high concentration in cancer cells, singlet oxygen generation through chemical excitation may evolve into an important therapeutic approach.

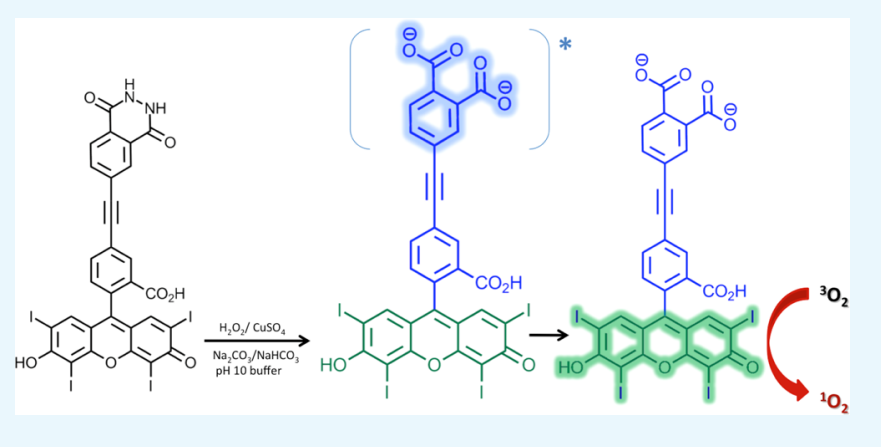

\section{INTRODUCTION}

Singlet oxygen is the primary cytotoxic agent involved in photodynamic therapy (PDT) of cancer. ${ }^{1}$ Generation of singlet oxygen requires a photosensitizer, dissolved molecular oxygen, and light of an appropriate wavelength for excitation of the photosensitizer. ${ }^{2}$ An excited photosensitizer should be capable of undergoing efficient intersystem crossing ${ }^{3}$ so that energy transfer to the ground-state molecular oxygen can take place. The fact that light is needed for the generation of singlet oxygen is both an advantage (increased spatial selectivity) and a disadvantage (light does not penetrate tissues to more than a few millimeters). Attenuation of light as it passes through tissues is one of the factors limiting the clinical practice of PDT to mostly superficial lesions. ${ }^{4}$ Despite considerable efforts to alleviate these problems with new light sources, photosensitizers, and novel delivery methods, they seem to remain as intractable as ever. ${ }^{5}$

There are proposed alternatives to in vivo irradiative generation of singlet oxygen, such as X-ray-induced scintillating nanoparticles $^{6}$ or persistent luminescent nanoparticles. The former approach attempts to excite using penetrating radiation, ${ }^{7}$ whereas the latter separates the excitation step from the singlet oxygen generation step. Recently, we also introduced the use of endoperoxide for the potential bypass of excitation altogether. ${ }^{8}$

In this work, our aim was to couple chemical excitation with singlet oxygen generation in a modular unimolecular system. The use of chemiluminescence or bioluminescence as a source of excitation for photosensitizers has been investigated previously. ${ }^{9}$ Unfortunately, the conditions for efficient (nonradiative) energy transfer required the use of a chemiluminescing agent and photosensitizer in large concentrations, limiting the potential of this approach at conception. However, a through-bond energy transfer to a photosensitizer would circumvent the problem caused by two independent agents by directly generating singlet oxygen upon chemical excitation. The synthesis of the target compound, 11, was done in multiple steps from commercially available products (Scheme 1). Compound 10 has been previously reported ${ }^{10}$ as an energytransfer cassette. The final step was halogenation of the xanthene nucleus to introduce heavy iodine atoms to facilitate intersystem crossing. As expected, iodination resulted in significant quenching of the fluorescence as it allows rapid access to the triplet manifold.

\section{RESULTS AND DISCUSSION}

The general design principle is shown in Figure 1. The idea is to bring the chemiluminegenic unit in close proximity to the photosensitizer, thus ensuring a highly effective concentration. The chemiluminescence energy is likely to be efficiently transferred by through-bond energy transfer, but considering the short distance that the chemiluminogen can be placed at in relation to the photosensitizer, a through-space energy transfer can be envisioned. On triggering of the chemiluminescence reaction, the resulting excited-state species would be expected to transfer their energy to the photosensitizer, which in turn would sensitize singlet oxygen. Hydrogen peroxide is particularly relevant and important as a trigger compound for two reasons: (i) it is known to be present in high concentrations in tumor cells, ${ }^{11}$ in fact high enough to trigger chemiluminescence and ${ }^{12}$ (ii) there are several different chemiluminogen systems (oxalates, acridinium esters, etc.) that can be activated by hydrogen peroxide.

Received: February 27, 2017

Accepted: March 27, 2017

Published: April 17, 2017 
Scheme 1. Synthesis of Compound 11 from Commercially Available and/or Easily Accessible Compounds ${ }^{a}$<smiles>COc1ccc(CCl)cc1</smiles>

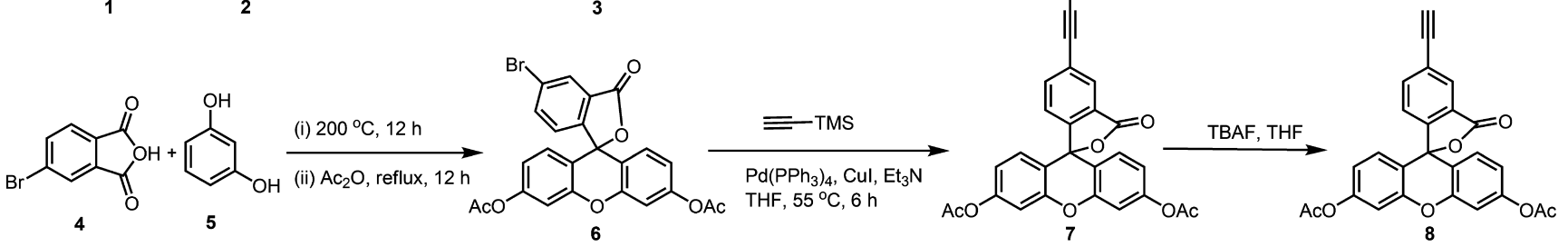

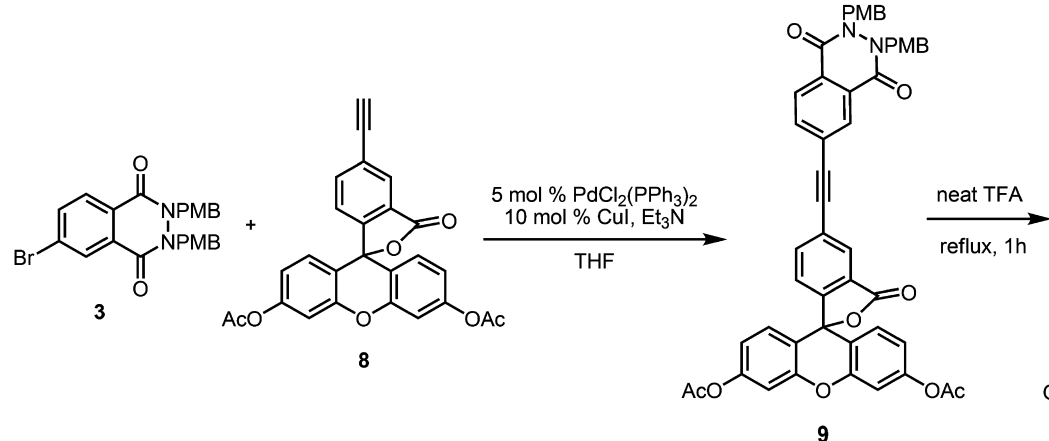

9<smiles>O=C(O)c1ccc(C#Cc2ccc3oc4cc(O)ccc4c(=O)[nH][nH]c(=O)c3c2)cc1C(=O)O</smiles>

10

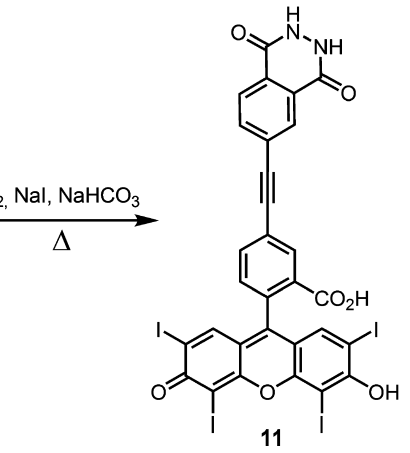

${ }^{a}$ The key intermediate, 10, was synthesized essentially following a previously published procedure. ${ }^{10}$

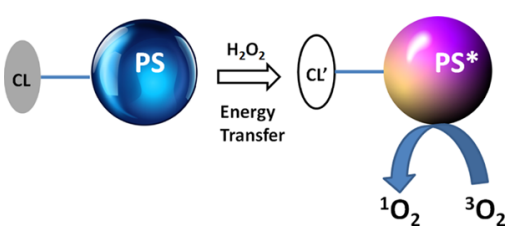

Figure 1. General principle for singlet oxygen generation via chemical excitation. Hydrogen peroxide would be a preferred initiator. CL: chemiluminogen module, PS: photosensitizer module, PS*: excited photosensitizer.

The absorption spectrum of compound 11 (Figure 2) shows one peak in the visible region at $530 \mathrm{~nm}$. Introduction of four iodo substituents causes a redshift in absorbance compared to that of a typical unsubstituted xanthene dye.

We first wanted to demonstrate that a tetraiodoxanthene (erythrosin)-derived module is satisfactory as a photosensitizer. To that end, a solution of the erythrosin-luminol conjugate was prepared in a DMSO-containing singlet oxygen trap, DPBF. When kept in the dark for $8 \mathrm{~min}$, there was no discernable change in the absorption spectrum (Figure 3). However, on irradiation with a green LED (520 nm, fluence rate $2.5 \mathrm{~mW} / \mathrm{cm}^{2}$ ), the absorption peak due to the trap compound, DPBF, rapidly disappeared in $14 \mathrm{~min}$. This indicates that the photosensitizer module, which is structurally related to erythrosin, retains a high level of photosensitization capacity within the bifunctional construct.

The chemical generation of singlet oxygen was then studied in DMSO solution (Figure 3) with a small amount of added aqueous buffer solution. Careful control experiments were performed to eliminate other potential sources of decrease in absorbance. The absorption of the singlet oxygen trap (DPBF, black squares) was followed in the presence of carbonate buffer (10\% buffer, $90 \%$ DMSO volume percentage), catalytic $\mathrm{Cu}^{2+}$,

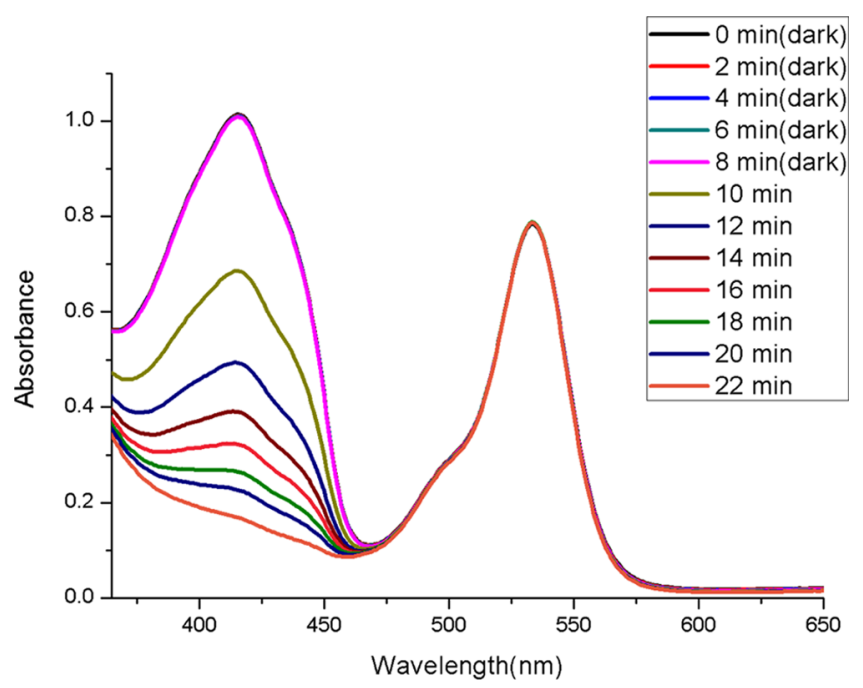

Figure 2. Reaction of the singlet oxygen generated by photosensitization with $47 \mu \mathrm{M}$ 1,3-diphenyl-isobenzofuran (DPBF) in dimethyl sulfoxide (DMSO) in the presence of erythrosine-luminol conjugate 11. For the first $8 \mathrm{~min}$, the solution was kept in the dark; thereafter, it was irradiated with a $520 \mathrm{~nm}$ light-emitting diode (LED) array for $16 \mathrm{~min}$. The total volume was adjusted to $3.0 \mathrm{~mL}$. Absorbance spectra were recorded in 2 min intervals.

and hydrogen peroxide (final concentration $0.20 \mathrm{mM}$ ). Compound 10 was also investigated under same conditions and showed no change (red circles). However, compound 11, added to the reaction mixture at $t=8.0 \mathrm{~min}$, resulted in a rapid decrease, leveling off, as expected, within $12 \mathrm{~min}$. This is also in accordance with the typical chemiluminescence kinetics of luminol under comparable conditions. Naturally, due to the solubility restrictions, the chemical excitation was tested under 


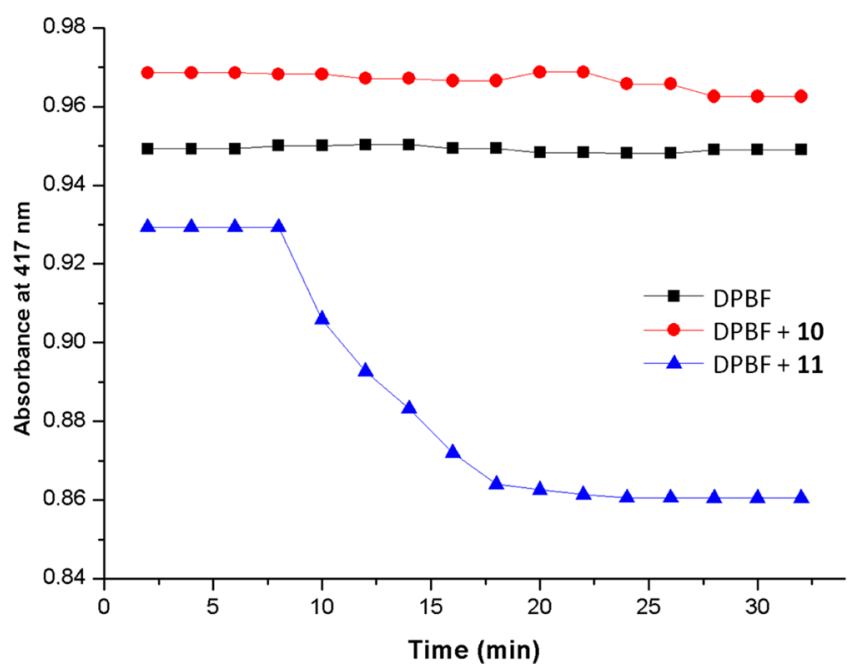

Figure 3. Change in the absorbance of $47.0 \mu \mathrm{M}$ DPBF in DMSO in the presence of $104.0 \mu \mathrm{M}$ of compound 10 or 11. The sample solutions contain $300 \mu \mathrm{L}$ of $\mathrm{pH} 10.0$ buffer solution $\left(\mathrm{Na}_{2} \mathrm{CO}_{3}\right.$ and $\mathrm{NaHCO}_{3}$ ). After $8 \mathrm{~min}$, chemical excitation is induced by $300 \mu \mathrm{L}$ of $1.5 \times 10^{-3} \mathrm{M} \mathrm{CuSO}_{4}$ and $2 \times 10^{-3} \mathrm{M} \mathrm{H}_{2} \mathrm{O}_{2}$. The total volume was adjusted to $3.0 \mathrm{~mL}$. Absorbance data were recorded in $2 \mathrm{~min}$ intervals.

highly suboptimal conditions. However, we estimated the chemical yield of singlet oxygen on the basis of the concentration of compound $\mathbf{1 1}$ and the decrease in the absorption of DPBF as $4.2 \%$, which is promising considering the chemical and photophysical processes involved in singlet oxygen generation. The yield is most likely held restricted by the solubility of molecular oxygen.

\section{CONCLUSIONS}

Our previous work ${ }^{8 b}$ demonstrated that a small amount of singlet oxygen generated within tumors may be sufficient to induce apoptosis. We are confident that with appropriate modifications to improve water solubility coupling singlet oxygen generation with hydrogen peroxide levels will evolve into a promising methodology for tumor therapy. Work in that direction is in progress in our laboratory.

\section{EXPERIMENTAL SECTION}

${ }^{1} \mathrm{H}$ NMR and ${ }^{13} \mathrm{C}$ NMR spectra were recorded on a Bruker DPX-400 spectrometer (operating at $400 \mathrm{MHz}$ for ${ }^{1} \mathrm{H}$ NMR and $100 \mathrm{MHz}$ for ${ }^{13} \mathrm{C}$ NMR). Chemical shifts are reported in units of parts per million relative to those of the solvent peak $\left(\mathrm{CDCl}_{3}: 7.27 \mathrm{ppm}\right.$ for ${ }^{1} \mathrm{H}$ and $77.0 \mathrm{ppm}$ for ${ }^{13} \mathrm{C} ; \mathrm{D}_{2} \mathrm{O}: 4.63$ ppm for ${ }^{1} \mathrm{H}$ ). All spectra were recorded at $25^{\circ} \mathrm{C}$, and the coupling constants ( $J$ values) are given in hertz. Chemical shifts are given in parts per million. Absorption spectra were recorded using a Varian Cary-100 spectrophotometer. Fluorescence measurements were conducted on a Varian Eclipse spectrofluorometer. Mass spectra were recorded on an Agilent Technologies 6530 Accurate-Mass Q-TOF LC/MS system. Reactions were monitored by thin-layer chromatography using Merck TLC Silica gel $60 \mathrm{~F}_{254}$. Silica gel column chromatography was performed over Merck Silica gel 60 (particle size: 0.040-0.063 mm, 230-400 mesh ASTM). Anhydrous tetrahydrofuran was obtained by refluxing over sodium/ benzophenone prior to use. All other reagents and solvents were purchased from Aldrich and used without further purification. DPBF was used as the singlet oxygen trap.
Compound 3. 6-Bromo-2,3-dihydrophthalazine-1,4-dione $(0.300 \mathrm{~g}, 1.24 \mathrm{mmol})$ was dissolved in $8.5 \mathrm{~mL}$ of dry DMF and cooled to $0{ }^{\circ} \mathrm{C}$. $\mathrm{NaH}(104.0 \mathrm{mg}, 2.6 \mathrm{mmol})$ was added, and the reaction mixture was stirred for $45 \mathrm{~min}$; then, 4-methoxybenzyl chloride $(0.36 \mathrm{~mL}, 2.6 \mathrm{mmol})$ was added dropwise. The reaction mixture was stirred at room temperature overnight, extracted with EtOAc $(3 \times 10 \mathrm{~mL})$, and then washed with water $(3 \times 10 \mathrm{~mL})$. The organic layer was dried with $\mathrm{Na}_{2} \mathrm{SO}_{4}$ and evaporated under reduced pressure. The product was purified by silica gel column chromatography using ethyl acetate/hexane $(10: 90, \mathrm{v} / \mathrm{v})$ as the mobile phase. The fraction containing compound 3 was collected, and then the solvent was removed under reduced pressure $(180 \mathrm{mg}, 30 \%) .{ }^{1} \mathrm{H}$ NMR $\left(400 \mathrm{MHz}, \mathrm{CDCl}_{3}\right) \delta 8.55(\mathrm{~s}, 1 \mathrm{H}), 7.81(\mathrm{~s}, 2 \mathrm{H}), 7.43(\mathrm{~d}, J=$ $8.6 \mathrm{~Hz}, 2 \mathrm{H}), 7.36(\mathrm{~d}, J=8.6 \mathrm{~Hz}, 2 \mathrm{H}), 6.92(\mathrm{~d}, J=8.6 \mathrm{~Hz}, 2 \mathrm{H})$, $6.87(\mathrm{~d}, J=8.6 \mathrm{~Hz}, 2 \mathrm{H}), 5.29(\mathrm{~s}, 2 \mathrm{H}), 5.24(\mathrm{~s}, 2 \mathrm{H}), 3.84(\mathrm{~s}$, $3 \mathrm{H}), 3.80(\mathrm{~s}, 3 \mathrm{H}) .{ }^{13} \mathrm{C} \mathrm{NMR}\left(100 \mathrm{MHz}, \mathrm{CDCl}_{3}\right) \delta 159.7$, 159.2 , 157.1, 149.2, 135.9, 130.6, 130.3, 130.1, 130.1, 129.2, $128.3,126.7,125.3,123.4,114.0,113.9,68.6,55.3,53.6 . \mathrm{MS}$ (TOF-ESI): $m / z$ : calcd: $481.0757[\mathrm{M}+\mathrm{H}]^{+}$, found: 481.0628 $[\mathrm{M}+\mathrm{H}]^{+}, \Delta=26.9 \mathrm{ppm}$.

Compound 6. In a round-bottom flask (100.0 mL), 4bromophthalic anhydride $(8.75 \mathrm{~g}, 38.6 \mathrm{mmol})$ and resorcinol $(8.50 \mathrm{~g}, 77.3 \mathrm{mmol})$ were heated for $12 \mathrm{~h}$. A dark brown solid was formed. After cooling, $60 \mathrm{~mL}$ of acetic anhydride was added, and then, the mixture was refluxed for $3 \mathrm{~h}$. The reaction mixture was cooled to room temperature slowly for recrystallization. Brownish crystals were collected and washed with cold acetic anhydride and then with cold ethanol. Recrystallization was repeated several times until white crystals were obtained. ${ }^{1} \mathrm{H}$ NMR $\left(400 \mathrm{MHz}, \mathrm{CDCl}_{3}\right) \delta 8.18(\mathrm{dd}, J=$ $1.7,0.4 \mathrm{~Hz}, 1 \mathrm{H}), 7.82(\mathrm{dd}, J=8.2,1.8 \mathrm{~Hz}, 1 \mathrm{H}), 7.14-7.11(\mathrm{~m}$, $2 \mathrm{H}), 7.10$ (dd, $J=8.3,0.4 \mathrm{~Hz}, 1 \mathrm{H}), 6.85(\mathrm{~s}, 4 \mathrm{H}), 2.34(\mathrm{~s}, 6 \mathrm{H})$. ${ }^{13} \mathrm{C}$ NMR $\left(100 \mathrm{MHz}, \mathrm{CDCl}_{3}\right) \delta 168.9,167.5,152.1,151.5$, 151.3 , 138.4, 128.7, 128.1, 125.6, 124.2, 117.9, 115.7, 110.5, 81.8, 20.9. MS (TOF-ESI): $m / z$ : calcd: $519.005[\mathrm{M}+\mathrm{Na}]^{+}$, found: $518.9966[\mathrm{M}+\mathrm{Na}]^{+}, \Delta=16.2 \mathrm{ppm}$.

Compound 7. 5-Bromofluorescein diacetate $6(250 \mathrm{mg}, 0.5$ $\mathrm{mmol})$, CuI (4.8 $\mathrm{mg}, 0.025 \mathrm{mmol})$, and palladium(tetrakistriphenylphosphine) $(17.5 \mathrm{mg}, 0.025 \mathrm{mmol})$ were added to $0.5 \mathrm{~mL}$ of dry tetrahydrofuran (THF) in a Schlenk flask under an argon atmosphere. Thereafter, $\mathrm{NEt}_{3}(0.7 \mathrm{~mL}, 5$ $\mathrm{mmol})$ was added followed by trimethylsillyl acetylene $(0.14$ $\mathrm{mL}, 1 \mathrm{mmol}$ ) and the reaction mixture was heated to $72{ }^{\circ} \mathrm{C}$ for $6 \mathrm{~h}$. The mixture was concentrated in vacuo and then purified by flash chromatography (25\% EtOAc/hexane). Pale yellow crystals were formed (yield: $170 \mathrm{mg}, 66 \%) .{ }^{1} \mathrm{H}$ NMR (400 $\left.\mathrm{MHz}, \mathrm{CDCl}_{3}\right) \delta 8.11(\mathrm{~s}, 1 \mathrm{H}), 7.75(\mathrm{dd}, J=8.0,1.4 \mathrm{~Hz}, 1 \mathrm{H})$, $7.14(\mathrm{~d}, J=8.0 \mathrm{~Hz}, 1 \mathrm{H}), 7.12-7.10(\mathrm{~m}, 2 \mathrm{H}), 6.85-6.81(\mathrm{~m}$, $4 \mathrm{H}), 2.32$ (s, 6H), 0.30 (s, 9H). ${ }^{13} \mathrm{C}$ NMR (100 MHz, $\mathrm{CDCl}_{3}$ ) $\delta 169.0,168.0,152.0,151.4,138.7,128.8,128.4,126.5,125.6$, $124.0,117.8,116.2,110.3,102.6,97.5,81.8,20.9,0.01$. MS (TOF-ESI): $m / z$ : calcd: $514.1448[\mathrm{M}+2 \mathrm{H}]^{+}$, found: 514.1418 $[\mathrm{M}], \Delta=5.8 \mathrm{ppm}$.

Compound 8. 5-(2-Trimethylsilylethynyl)fluorescein diacetate $7(200 \mathrm{mg}, 0.389 \mathrm{mmol})$ was dissolved in $6 \mathrm{~mL}$ of dry THF. Then, tetra- $n$-butylammonium fluoride $(0.39 \mathrm{~mL}, 1.0 \mathrm{M}$ in THF) was added, and the mixture was concentrated in vacuo. The crude orange solid obtained was purified by flash chromatography (25\% EtOAc/hexane). ${ }^{1} \mathrm{H}$ NMR (400 MHz, $\left.\mathrm{CDCl}_{3}\right) \delta 8.14(\mathrm{~s}, 1 \mathrm{H}), 7.78(\mathrm{dd}, J=7.9 \mathrm{~Hz}, 1.4 \mathrm{~Hz}, 1 \mathrm{H}), 7.17$ $(\mathrm{d}, J=7.9 \mathrm{~Hz}, 1 \mathrm{H}), 7.14-7.11(\mathrm{~m}, 2 \mathrm{H}), 6.87-6.83(\mathrm{~m}, 4 \mathrm{H})$, $3.25(\mathrm{~s}, 1 \mathrm{H}), 2.33(\mathrm{~s}, 6 \mathrm{H}) \cdot{ }^{13} \mathrm{C} \mathrm{NMR}\left(100 \mathrm{MHz}, \mathrm{CDCl}_{3}\right) \delta$ 
$168.8,168.1,152.6,152.2,151.6,138.8,128.8,128.7,126.5$, $124.6,124.2,117.8,115.9,110.5,81.7,81.5,79.8,21.3$. MS (TOF-ESI): $m / z$ : calcd: $465.0945[\mathrm{M}+\mathrm{Na}]^{+}$, found: 465.0856 $[\mathrm{M}+\mathrm{Na}]^{+}, \Delta=19.1 \mathrm{ppm}$.

Compound 9. Compound 3 (335 $\mathrm{mg}, 0.699 \mathrm{mmol}$ ) and compound 6 (335 mg, $0.769 \mathrm{mmol}$ ), bis(triphenylphosphine) palladium chloride $(26.0 \mathrm{mg}, 0.065 \mathrm{mmol})$, copper(I) iodide (13 mg, $0.13 \mathrm{mmol}), \mathrm{NEt}_{3}(0.98 \mathrm{~mL}, 6.99 \mathrm{mmol})$, and $8.0 \mathrm{~mL}$ of dry THF were added into a microwave tube. The reaction mixture was microwave-irradiated at $120{ }^{\circ} \mathrm{C}$ for about $25 \mathrm{~min}$. The solvent was removed under reduced pressure, and the product was purified by silica gel column chromatography using ethyl acetate/hexane $(25: 75, \mathrm{v} / \mathrm{v})$ as the mobile phase. White crystals were formed (262 mg, 45\%). ${ }^{1} \mathrm{H}$ NMR (400 MHz, $\left.\mathrm{CDCl}_{3}\right) \delta 8.58(\mathrm{~s}, 1 \mathrm{H}), 8.19(\mathrm{~s}, 1 \mathrm{H}), 7.96(\mathrm{~d}, J=8.3 \mathrm{~Hz}, 1 \mathrm{H})$, $7.90-7.84(\mathrm{~m}, 2 \mathrm{H}), 7.45(\mathrm{~d}, J=8.5 \mathrm{~Hz}, 2 \mathrm{H}), 7.40(\mathrm{~d}, J=8.5$ $\mathrm{Hz}, 2 \mathrm{H}), 7.22(\mathrm{~d}, J=8.0 \mathrm{~Hz}, 1 \mathrm{H}), 7.12(\mathrm{~s}, 2 \mathrm{H}), 6.98-6.82(\mathrm{~m}$, $8 \mathrm{H}), 5.30(\mathrm{~s}, 2 \mathrm{H}), 5.26(\mathrm{~s}, 2 \mathrm{H}), 3.83(\mathrm{~s}, 3 \mathrm{H}), 3.79(\mathrm{~s}, 3 \mathrm{H}), 2.33$ $(\mathrm{s}, 6 \mathrm{H}) .{ }^{13} \mathrm{C} \mathrm{NMR}\left(100 \mathrm{MHz}, \mathrm{CDCl}_{3}\right) \delta 168.8,168.1,159.6$, $159.2,157.6,152.6,152.2,151.5,149.2,138.4,135.2,130.6$, $130.3,130.1,129.3,129.2,128.9,128.3,126.6,126.0,125.0$, $124.3,124.2,123.8,117.9,115.9,113.9,113.8,110.5,90.4$, $81.83,68.5,55.2,53.5,21.1$. MS (TOF-ESI): $\mathrm{m} / z$ : calcd: 842.2476 [M] $]^{+}$, found: $842.2399[\mathrm{M}]^{+}, \Delta=9.1 \mathrm{ppm}$.

Compound 10. Compound $9(80.0 \mathrm{mg}, 0.01 \mathrm{mmol})$ and $8.0 \mathrm{~mL}$ of TFA were mixed and heated to $70{ }^{\circ} \mathrm{C}$ for $1 \mathrm{~h}$. The mixture was concentrated in vacuo. The reaction product was dissolved in $2.0 \mathrm{~mL}$ of $1.0 \mathrm{M} \mathrm{NaOH}$. Then, two drops of $\mathrm{HCl}$ were added, and a yellow-orange solid precipitated. The precipitate was filtrated and washed with water and EtOAc. A yellow solid was afforded (36 mg, 75\%). ${ }^{1} \mathrm{H}$ NMR (400 MHz, $\left.\mathrm{D}_{2} \mathrm{O}\right) \delta 7.88(\mathrm{~s}, 1 \mathrm{H}), 7.83(\mathrm{~s}, 1 \mathrm{H}), 7.79(\mathrm{~d}, J=8.2 \mathrm{~Hz}, 1 \mathrm{H})$, $7.58(\mathrm{~d}, J=7.8 \mathrm{~Hz}, 1 \mathrm{H}), 7.47(\mathrm{~d}, J=8.2 \mathrm{~Hz}, 1 \mathrm{H}), 7.24(\mathrm{~d}, J=$ $7.8 \mathrm{~Hz}, 1 \mathrm{H}), 7.01(\mathrm{~d}, J=9.3 \mathrm{~Hz}, 2 \mathrm{H}), 6.47(\mathrm{~d}, J=9.3 \mathrm{~Hz}, 2 \mathrm{H})$, 6.33 (s, 2H). MS (TOF-ESI): $m / z$ : calcd: $517.103[\mathrm{M}+\mathrm{H}]^{+}$, found: $517.0966[\mathrm{M}+\mathrm{H}]^{+}, \Delta=12.4 \mathrm{ppm}$.

Compound 11. Compound 10 (16.0 mg, $0.03 \mathrm{mmol}$ ), 0.5 $\mathrm{mL}$ of saturated sodium bicarbonate solution, $0.5 \mathrm{~mL}$ of $0.1 \mathrm{M}$ $\mathrm{NaI}$ solution, and $31.4 \mathrm{mg}$ of iodine were mixed and refluxed for about $40 \mathrm{~min}$. The mixture was cooled to room temperature and $0.4 \mathrm{~mL}$ of $\mathrm{H}_{2} \mathrm{SO}_{4}$ was added and extracted with EtOAc. The aqueous layer was separated, and the organic layer was washed with water two times. Finally, the organic layer was washed with $10 \%$ sodium thiosulfate solution. A faint red solid was afforded (5.0 mg, 15\%). ${ }^{1} \mathrm{H}$ NMR (400 MHz, MeOD) $\delta$ $8.41(\mathrm{~s}, 1 \mathrm{H}), 8.32-8.16(\mathrm{~m}, 2 \mathrm{H}), 7.96(\mathrm{~d}, J=8.2 \mathrm{~Hz}, 1 \mathrm{H}), 7.78$ $(\mathrm{d}, J=8.0 \mathrm{~Hz}, 1 \mathrm{H}), 7.30(\mathrm{~d}, J=7.9 \mathrm{~Hz}, 1 \mathrm{H}), 7.09(\mathrm{~d}, J=9.3$ $\mathrm{Hz}, 2 \mathrm{H}), 6.68-6.39$ (m, 4H). MS (TOF-ESI): $m / z$ : calcd for $\mathrm{C}_{30} \mathrm{H}_{13} \mathrm{I}_{3} \mathrm{~N}_{2} \mathrm{O}_{7}: 893.78568[\mathrm{M}-\mathrm{I}-\mathrm{H}]^{+}$, found: 893.74085 $[\mathrm{M}], \Delta=50.2 \mathrm{ppm}$.

\section{ASSOCIATED CONTENT}

\section{S Supporting Information}

The Supporting Information is available free of charge on the ACS Publications website at DOI: 10.1021/acsomega.7b00228.

Synthesis procedures and additional spectral and characterization data, including ${ }^{1} \mathrm{H} \mathrm{NMR},{ }^{13} \mathrm{C} \mathrm{NMR}$, and HRMS data (PDF)

\section{AUTHOR INFORMATION}

\section{Corresponding Author}

*E-mail: eua@fen.bilkent.edu.tr. Tel: +90-312-290-3570.

\section{ORCID}

\section{Engin U. Akkaya: 0000-0003-4720-7554}

\section{Author Contributions}

The manuscript was written through contributions from all authors. All authors have given approval to the final version of the manuscript.

\section{Notes}

The authors declare no competing financial interest.

\section{ACKNOWLEDGMENTS}

Financial support from Bilkent University in the form of a graduate student scholarship to N.Y. is gratefully acknowledged.

\section{REFERENCES}

(1) (a) Agostinis, P.; Berg, K.; Cengel, K. A.; Foster, T. H.; Girotti, A. W.; Gollnick, S. O.; Hahn, S. M.; Hamblin, M. R.; Juzeniene, A.; Kessel, D.; Korbelik, M.; Moan, J.; Mroz, P.; Nowis, D.; Piette, J.; Wilson, B. C.; Golab, J. Ca-Cancer J. Clin. 2011, 61, 250-281. (b) O'Connor, A. E.; Gallagher, W. M.; Byrne, A. T. Photochem. Photobiol. 2009, 85, 1053-1074. (c) Juzeniene, A.; Peng, Q.; Moan, J. Photochem. Photobiol. Sci. 2007, 6, 1234-1245.

(2) (a) Dolmans, D. E. J. G. J.; Fukumura, D.; Jain, R. K. Nat. Rev. Cancer 2003, 3, 380-387. (b) Castano, A. P.; Demidova, T. N.; Hamblin, M. R. Photodiagn. Photodyn. Ther. 2004, 1, 279-293. (c) Ozlem, S.; Akkaya, E. U. J. Am. Chem. Soc. 2009, 131, 48-49. (d) Yukruk, F.; Dogan, A. L.; Canpinar, H.; Guc, D.; Akkaya, E. U. Org. Lett. 2005, 7, 2885-2887. (e) Erbas, S.; Gorgulu, A.; Kocakusakogullari, M.; Akkaya, E. U. Chem. Commun. 2009, 49564958. (f) Atilgan, S.; Ekmekci, Z.; Dogan, A. L.; Guc, D.; Akkaya, E. U. Chem. Commun. 2006, 4398-4400. (g) Dougherty, T. J.; Gomer, C. J.; Henderson, B. W.; Jori, G.; Kessel, D.; Korbelik, M.; Moan, J.; Peng, Q. J. Natl. Cancer Inst. 1998, 90, 889-905. (h) Kolemen, S.; Isik, M.; Kim, G. M.; Kim, D.; Geng, H.; Buyuktemiz, M.; Karatas, T.; Zhang, X.-F.; Dede, Y.; Yoon, J.; Akkaya, E. U. Angew. Chem., Int. Ed. 2015, 54, $5340-5344$

(3) (a) Moan, J.; Peng, Q. Anticancer Res. 2003, 23, 3591-3600. (b) Ozdemir, T.; Bila, J. L.; Sozmen, F.; Yildirim, L. T.; Akkaya, E. U. Org. Lett. 2016, 18, 4821-4823. (c) Adarsh, N.; Avirah, R. R; Ramaiah, D. Org. Lett. 2010, 12, 5720-5723. (d) Awuah, S. G.; Polreis, J.; Biradar, V.; You, Y. Org. Lett. 2011, 13, 3884-3887.

(4) Stolik, S.; Delgado, J. A.; Perez, A.; Anasagasti, L. J. Photochem. Photobiol., B 2000, 57, 90.

(5) (a) Erbas-Cakmak, S.; Akkaya, E. U. Org. Lett. 2014, 16, 29462949. (b) Klaper, M.; Fudickar, W.; Linker, T. J. Am. Chem. Soc. 2016, 138, 7024-7029.

(6) (a) Clement, S.; Deng, W.; Camilleri, E.; Wilson, B. C.; Goldys, E. M. Sci. Rep. 2016, 6, No. 19954. (b) Liu, Y.; Chen, W.; Wang, S.; Joly, A. G. Appl. Phys. Lett. 2008, 92, No. 043901.

(7) Bulin, A.-L.; Truillet, C.; Chouikrat, R.; Lux, F.; Frochot, C.; Amans, D.; Ledoux, G.; Tillement, O.; Perriat, P.; Barberi-Heyob, M.; Dujardin, C. J. Phys. Chem. C 2013, 117, 21583-21589.

(8) (a) Turan, I. S.; Yildiz, D.; Turksoy, A.; Gunaydin, G.; Akkaya, E. U. Angew. Chem., Int. Ed. 2016, 55, 2875-2878. (b) Kolemen, S.; Ozdemir, T.; Lee, D.; Kim, G. M.; Karatas, T.; Yoon, J.; Akkaya, E. U. Angew. Chem., Int. Ed. 2016, 128, 3670-3674.

(9) (a) Theodossiou, T.; Hothersall, J. S.; Woods, E. A.; Okkenhaug, K.; Jacobson, J.; MacRobert, A. J. Cancer Res. 2003, 63, 1818-1821. (b) Yuan, H.; Chong, H.; Wang, B.; Zhu, C.; Liu, L.; Yang, Q.; Lv, F.; Wang, S. J. Am. Chem. Soc. 2012, 134, 13184-13187. (c) Laptev, R.; Nisnevitch, M.; Siboni, G.; Malik, Z.; Firer, M. A. Br. J. Cancer 2006, 95, 189-196. (d) Bancirova, M.; Lasovsky, J. Luminescence 2011, 26, 410-415. (e) Phillip, M. J.; Maximuke, P. P. Oncology 1989, 46, 266272. (f) Magalhães, C. M.; da Silva, J. C. G. E.; da Silva, L. P. ChemPhysChem 2016, 17, 2286-2294.

(10) Han, J.; Jose, J.; Mei, E.; Burgess, K. Angew. Chem., Int. Ed. 2007, $46,1684-1687$. 
(11) (a) Szatrowski, T. P.; Nathan, C. F. Cancer Res. 1991, 51, 794798. (b) Glasauer, A.; Chandel, N. S. Biochem. Pharmacol. 2014, 92, 90-101.

(12) Lee, D.; Khaja, S.; Velasquez-Castano, J. C.; Dasari, M.; Sun, C.; Petros, J.; Taylor, W. R.; Murthy, N. Nat. Mater. 2007, 6, 765-769. 